\title{
Why is Mortality Low among the Swedish-Speaking Minority in Finland?
}

\author{
SEPPO KOSKINEN MD, M.Sc., Chief Physician ${ }^{1,2}$
} TUIJA MARTELIN Ph.D., Senior Researcher ${ }^{1,2}$

\footnotetext{
${ }^{1}$ National Public Health Institute (KTL), Department of Health and Functional Capacity, Helsinki, Finland

2 Population Research Unit, Department of Sociology, University of Helsinki, Finland
}

\section{Abstract}

Life expectancy has been substantially longer among the Swedish-speaking Finns than in the rest of the population. The relative mortality difference appears to be particularly marked among the middle-aged. This study examines the possible reasons for this mortality difference.

The mortality advantage of the Swedish-speaking Finns is connected with their more favorable geographic location and socioeconomic position. For women these factors explain all of the mortality difference but among men two-thirds of the original difference, a 20\% excess mortality of the Finnish-speaking majority, persists after adjusting for the structural differences. In men, the main part of the mortality difference results from factors responsible for excess mortality of the Finnish-speaking population from cardiovascular diseases and non-natural causes of death. A similar mortality contrast is seen in women as well, but it is compensated by other causes of death which are more common among Swedish-speaking than among Finnish-speaking women.

Keywords: mortality, cause of death, Finland, language, ethnic groups, minority groups 


\section{Introduction}

In international comparison life expectancy is very high in the Nordic countries. Sweden, Norway and Iceland, in particular, have been among the small number of leading countries throughout the 20th century. Finland constitutes an exception among the Nordic countries, although it has been drawing closer to the others during recent decades. The mortality of Finnish men, in particular, has been higher than the average level in the western industrialized countries (Valkonen 1991; Statistics Finland 2001a).

There is a significant ethnic minority, comprising nearly six percent of the total Finnish population, however, with clearly lower-than-average mortality. Among the Swedishspeaking Finns, life expectancy has been substantially longer than in the rest of the population. The earliest data, presented by Fougstedt (1951), cover the period 193645 , when the proportion of Swedish speakers was $10 \%$ of the whole population. At that time women's life expectancy was 3.5 years higher in the Swedish-speaking section than in the population as a whole. Among men the corresponding difference was 2.5 years. Among men the mortality difference between the language groups has been quite constant, whereas among women mortality has declined more slowly in the Swedish-speaking minority than in the Finnish-speaking population. At the beginning of the 1990s the difference in life expectancy had diminished to one year among women but remained at 2.5 years among men (Finnäs 1995, 9). During the 1990s the relative mortality differences between the two language groups remained rather stable (Statistics Finland 2001b, 90-91).

In the early 1940s the relative mortality difference between language groups was clearly largest among infants and small children. In the adult age groups the difference tended to be much smaller, particularly among men (Fougstedt 1951, 225-227; Central Statistical Office of Finland 1952, 48). By the late 1970s the excess mortality of Finnishspeaking boys had totally disappeared. The relative advantage of Swedish-speaking girls had remained at the earlier level (Finnäs 1986, 44), but its impact on life expectancy had practically disappeared due to the rapid decline of death rates among girls in both language groups. In the adult age groups the relative contrast has, since the 1940s, somewhat declined among women and increased among men (Finnäs 1986, 1995).

The Swedish-speaking population in Finland appears to be healthier than the Finnishspeaking majority also according to indicators other than mortality. For example, disability pensions (Hyyppä and Mäki 2001a), occupational accidents (Salminen and Johansson 2000) and poor self-reported health among schoolchildren (Suominen et al. 2000) as well as among adults (Hyyppä and Mäki 2001b) are less frequent among Swedish-speaking than among Finnish-speaking Finns. 
Significant linguistic minorities exist in most European countries (e.g. Stephens 1976; Allardt 1979), but in most countries mortality differences between language groups have not been studied extensively. Many examples of mortality contrasts between language groups within national populations have been reported, however, concerning both rather recent immigrants (e.g. Balarajan et al. 1984; Bollini and Siem 1995; Wild and Mckeigue 1997; Uitenbroek and Verhoeff 2002) and indigenous population groups (e.g. Kornitzer et al. 1979)

The aim of this study is to delineate the reasons for the mortality difference between the language groups by means of analyzing a data set comprising the deaths during 1971-85 among the entire Finnish population, linked to the censuses of 1970, 1975 and 1980. The analysis is restricted to the age group 35-64 years which makes a particularly large contribution to the difference in life expectancy at birth between the language groups. We will start by reviewing the areas where the causes for the mortality contrast could lie.

\section{Possible causes}

It seems unlikely that the language spoken by an individual would directly affect her or his health status. Instead, we regard language as an indicator of membership of an ethnic group. Mortality differences between ethnic groups, as well as differences between subgroups of the population in general, may result from any factor or set of factors affecting the probability of death, providing that the prevalence of this determinant varies between the groups which are compared. The origin of mortality differences may thus lie in variations in the environment as well as in health-related behavior, genetic dissimilarities and differences in the nature and extent of health-related mobility to and from the population group.

Many alternative explanations may be relevant. First, the low mortality among the Swedish-speaking Finns may be due to a favorable population structure with regard to other sociodemographic factors. Most Swedish speakers live in the southern and western coastal parts of the country where mortality is known to be lowest. Furthermore, the proportion of persons who are married or belong to upper socioeconomic groups is higher in the Swedish-speaking sector than in the rest of the population (Central Statistical Office of Finland 1987, 31-32; Allardt and Starck 1981; Sandlund 1985). In these groups, death rates are significantly lower than average (Valkonen et al. 1993; Koskinen and Martelin 1994). Whatever the ultimate reasons for these sociodemographic mortality differences are, it seems quite possible that a major part of the low mortality in the Swedish-speaking group could simply be attributed to their favorable population structure. 
Contrary to the structural explanation, the cultural and genetic explanations share the basic assumption that membership in a linguistic minority has an independent effect on one's health status. The cultural hypothesis suggests that being a member of a linguistic or ethnic group affects several aspects of one's social environment and way of life. It may, for example, have implications on one's health-related behavior, such as patterns of drinking or eating. In addition, psychosocial factors, for example, such as social support and patterns of experiencing and dealing with stressful situations, may differ between the language groups. Hyyppä has postulated that the low mortality of the Swedish-speaking group results from their social capital, which gives them better support than in the Finnish-speaking population (Hyyppä 1994; Hyyppä and Mäki 200la).

Genetic characteristics can also produce mortality contrasts between the language groups if the beneficial traits are particularly common in the Swedish-speaking population. There seem to be some genetic differences between the language groups (Virtaranta-Knowles et al. 1991), owing to the history of the settlement of Finland.

Health-related mobility from one language group to another can hardly play a significant role in generating mortality differences between the groups. Changing one's language is rather infrequent (Finnäs 1986, 51-70) and there is no evidence or reason to suspect that changing one's language would be significantly influenced by one's health.

\section{Data, strategy and methods}

The data set of this study was constructed by linking individual records of the 1970, 1975 and 1980 Censuses with death records for the subsequent five-year periods 197175, 1976-80 and 1981-85, through the cooperative efforts of Statistics Finland ${ }^{1}$ and the research group at the Department of Sociology, University of Helsinki (Valkonen et al. 1990; Valkonen et al. 1993). It includes all the 172,000 deaths in the age group 35-64 in 1971-85 in Finland. The coverage of the data can be regarded as excellent since less than $0.5 \%$ of the deaths in Finland during 1971-85 are missing from the files, mainly due to undercoverage of the census data. The compilation of the data set has been described in detail earlier (Valkonen et al. 1990; Koskinen 1994; Martelin 1994). The data set does not cover the most recent years, but this does not diminish its value, as the relative mortality differences have remained more or less similar for several decades.

Table 1 shows the classification of causes of death. The variables used in the analysis as well as their classifications are presented in Table 2, which also gives the numbers

\footnotetext{
${ }^{1}$ We are indebted to Statistics Finland for the permission (TK 53-69-87) to use the data files.
} 
of person-years and deaths in each class. In the data set, age is continuously updated during the follow-up so that it refers to the exact age at any time during the follow-up. Other census variables, on the other hand, describe the situation at the time of the census. Possible changes in place of residence, occupation, education, marital status or language during the five-year follow-up are not included in the data.

Table 1. Deaths by cause of death, gender and language in 1971-85 in Finland in the 35-64-year-old population.

\begin{tabular}{lrrrr}
\hline Cause of death & \multicolumn{2}{c}{$\begin{array}{c}\text { Swedish-speaking } \\
\text { Women }\end{array}$} & Men & \multicolumn{2}{c}{$\begin{array}{c}\text { Finnish-speaking } \\
\text { Women }\end{array}$} & Men \\
\hline Ischemic heart disease & 560 & 2,519 & 9,034 & 43,233 \\
Other cardiovascular diseases & 551 & 786 & 9,635 & 14,623 \\
Lung cancer & 111 & 641 & 1,022 & 9,430 \\
Other neoplasms & 1,426 & 1,195 & 15,882 & 13,340 \\
Respiratory diseases & 118 & 243 & 1,380 & 4,293 \\
Other diseases & 450 & 627 & 6,134 & 9,760 \\
Suicide & 123 & 296 & 1,834 & 6,380 \\
Other violence and accidents & 162 & 590 & 2,878 & 12,664 \\
& & & & \\
All causes & $\mathbf{3 , 5 0 1}$ & $\mathbf{6 , 8 9 7}$ & $\mathbf{4 7 , 7 9 9}$ & $\mathbf{1 1 3 , 7 2 3}$ \\
\hline
\end{tabular}

With regard to the alternative explanations of the mortality difference, we are able to directly examine the hypothesis suggesting that the gap between the language groups is due to differences in their sociodemographic structure. If, on the other hand, mortality differentials persist even after controlling for sociodemographic structure, we may conclude that language has an independent effect on mortality. It is, however, a more difficult challenge to specify the mechanisms because behavioral and other cultural factors as well as genetic characteristics of individuals are not included in the data. Conclusions about the impact of these factors will therefore rely on indirect conclusions based on findings from the analyses concerning causes of death, as well as subgroups of the population.

There are many behavioral factors which may contribute to the mortality difference. If smoking is the major cause of the mortality difference between the Swedish- and Finnish-speaking groups, after having controlled for the population structure, we should see the largest mortality differences in those causes of death which are strongly related with smoking. A particularly extensive contrast could thus be expected in lung cancer, a somewhat weaker one in respiratory diseases and a rather small one in other cancers and cardiovascular diseases, while in mortality from other diseases and nonnatural deaths the language groups may not differ from each other. Differences caused by smoking can be expected to be larger in men as the prevalence of smoking has been much greater among men than among women (Martelin 1984). 
Table 2. Person years and numbers of deaths by language in subgroups of the $35-$ 64-year-old population in Finland in 1971-1985.

\begin{tabular}{|c|c|c|c|c|c|c|c|c|}
\hline \multirow{3}{*}{ Subgroup } & \multicolumn{4}{|c|}{ Swedish-speaking } & \multicolumn{4}{|c|}{ Finnish-speaking } \\
\hline & \multicolumn{2}{|c|}{ Women } & \multicolumn{2}{|c|}{ Men } & \multicolumn{2}{|c|}{ Women } & \multicolumn{2}{|c|}{ Men } \\
\hline & $\begin{array}{r}\text { Person } \\
\text { years, \% } \\
\end{array}$ & Deaths & $\begin{array}{r}\text { Person } \\
\text { years, \% }\end{array}$ & Deaths & $\begin{array}{r}\text { Person } \\
\text { years, \% } \\
\end{array}$ & Deaths & $\begin{array}{r}\text { Person } \\
\text { years, \% }\end{array}$ & Deaths \\
\hline All & $\begin{array}{r}100 \\
(847,000)\end{array}$ & 3,501 & $\begin{array}{r}100 \\
(803,000)\end{array}$ & 6,897 & $\begin{array}{r}100 \\
(11,943,000)\end{array}$ & 47,799 & $\begin{array}{r}100 \\
(10,913,000)\end{array}$ & 113,723 \\
\hline \multicolumn{9}{|l|}{ Age } \\
\hline $35-39$ & 16 & 97 & 19 & 268 & 19 & 2,216 & 21 & 6,504 \\
\hline $40-44$ & 15 & 169 & 16 & 360 & 17 & 3,190 & 19 & 9,069 \\
\hline $45-49$ & 15 & 334 & 16 & 612 & 17 & 4,722 & 18 & 14,022 \\
\hline $50-54$ & 17 & 481 & 17 & 1,120 & 17 & 7,462 & 16 & 20,202 \\
\hline $55-59$ & 18 & 904 & 17 & 1,785 & 16 & 11,616 & 14 & 27,232 \\
\hline $60-64$ & 19 & 1,516 & 16 & 2,752 & 15 & 18,593 & 12 & 36,694 \\
\hline \multicolumn{9}{|l|}{ Education } \\
\hline More than basic & 31 & 727 & 38 & 1,760 & 27 & 7,698 & 30 & 19,780 \\
\hline Basic & 69 & 2,774 & 62 & 5,137 & 73 & 40,101 & 70 & 93,943 \\
\hline \multicolumn{9}{|l|}{$\begin{array}{l}\text { Occupational } \\
\text { class }\end{array}$} \\
\hline White-collar & 49 & 1,433 & 37 & 2,026 & 37 & 12,714 & 26 & 19,907 \\
\hline Blue-collar & 28 & 1,131 & 36 & 2,943 & 40 & 21,796 & 51 & 64,464 \\
\hline Farmer & 16 & 559 & 18 & 1,294 & 16 & 9,281 & 16 & 20,865 \\
\hline Others & 7 & 378 & 9 & 634 & 6 & 4,008 & 7 & 8,487 \\
\hline \multicolumn{9}{|l|}{ Marital status } \\
\hline Married & 75 & 2,179 & 83 & 5,177 & 72 & 27,986 & 79 & 78,557 \\
\hline Others & 25 & 1,322 & 17 & 1,720 & 28 & 19,813 & 21 & 35,166 \\
\hline \multicolumn{9}{|l|}{ Region } \\
\hline Aland & 6 & 151 & 7 & 397 & 0 & 12 & 0 & 26 \\
\hline Vaasa province & 32 & 988 & 33 & 2,107 & 7 & 3,389 & 7 & 7,593 \\
\hline $\begin{array}{l}\text { Turku \& Pori } \\
\text { prov. }\end{array}$ & 9 & 336 & 10 & 705 & 15 & 7,178 & 15 & 15,697 \\
\hline Helsinki region ${ }^{\mathrm{a}}$ & 27 & 1,076 & 24 & 1,804 & 16 & 7,715 & 15 & 16,135 \\
\hline Other Uusimaa & 24 & 872 & 25 & 1,731 & 6 & 2,587 & 6 & 6,215 \\
\hline Other regions & 2 & 78 & 2 & 153 & 55 & 26,918 & 57 & 68,057 \\
\hline \multicolumn{9}{|l|}{$\begin{array}{l}\text { Level of } \\
\text { urbanization }\end{array}$} \\
\hline Urban areas & 68 & 2,396 & 65 & 4,438 & 68 & 30,840 & 64 & 66,913 \\
\hline Rural areas & 32 & 1,105 & 35 & 2,459 & 32 & 16,959 & 36 & 46,810 \\
\hline
\end{tabular}

${ }^{\mathrm{a}}$ The Helsinki region includes Helsinki, Espoo, Vantaa and Kauniainen.

If alcohol consumption has a significant role, we may assume that the mortality differences are especially large in accidental and violent causes of death, as well as in the group "other diseases" which includes alcoholism, liver cirrhosis and diseases of the pancreas, for example. Mortality contrasts caused by drinking should be particularly apparent in men since men drink, on average, much more than women and their drinking habits tend to be more extreme (Simpura 1987). Conclusions about the role of dietary habits are difficult to draw because none of the causes of death can be interpreted as an indicator of an excess intake or a shortage of a certain substance. The possible effect of varying fat and salt consumption may, however, be seen in cardiovascular diseases. 
If more or less permanent cultural traditions, such as social interaction patterns, are the main ultimate cause of low mortality among the Swedish speakers, those Swedishspeaking population groups which have best retained their original cultural features might be anticipated to be in the most advantaged position. Such groups may include residents of rural areas, perhaps farmers in particular, in those regions where the Swedish-speaking group forms the majority of the population.

Finally, if genetic factors are important causes of the mortality differential between the language groups, the contrast ought to be largest in causes of death where the role of inherited factors is greatest. It is unfortunately not possible to classify causes of death reliably according to this dimension but some causes, such as lung cancer, obviously result mainly from environmental and behavioral factors. Secondly, if genetic factors play an important role, the mortality difference should be largest in those areas where the Swedish-speaking group has best retained its genetic characteristics. Such areas may be Aland and the coastal (rural) parts of the province of Vaasa. In the Helsinki Region, for example, the population groups are probably more mixed in terms of genetic properties.

The analysis is based on a multivariate table for which the data are cross-tabulated according to all the variables included in Table 2. Each cell in this table gives the number of deaths and the number of person-years during the study period. The table is analyzed employing Poisson regression analysis of the mortality rates (Aitkin and Clayton 1980). The analyses are performed using the GLIM package (Payne 1985).

The analysis proceeds in three steps. First, the role of differences in population structure is examined by means of controlling for the other sociodemographic factors (age, education, occupational class, marital status, region of residence and level of urbanization) with the model. Second, the mortality difference between the language groups is examined separately within sociodemographic subgroups in order to find out whether the gap is particularly prominent in certain parts of the population. Cause-specific mortality differences are studied as the third step of the analysis.

\section{The role of population structure}

Age-standardized mortality was seven percent lower among Swedish-speaking women than among the other women during the period 1971-85 (relative mortality $=0.93$; Table 3a). Adding other sociodemographic variables to the explanatory model in Table 3a shows that this advantage disappears totally when differences in the population structure are controlled for. This is partly due to the higher-than-average education and occupational class of the Swedish-speaking women in comparison with the other women. Also the geographic location of the Swedish speakers is favorable, with respect to risk of death, even when the socioeconomic structure of the regional popula- 
tions has been adjusted for. Members of the upper socioeconomic strata and persons living in the southwest have lower-than-average mortality, and for women the advantageous socioeconomic and geographic location of the Swedish speakers seems to explain their low mortality totally.

Table 3a. Mortality of Swedish-speaking Finns relative to other Finns (=1.00) according to different models ${ }^{\mathrm{a}}$ in women aged 35-64 in 1971-85.

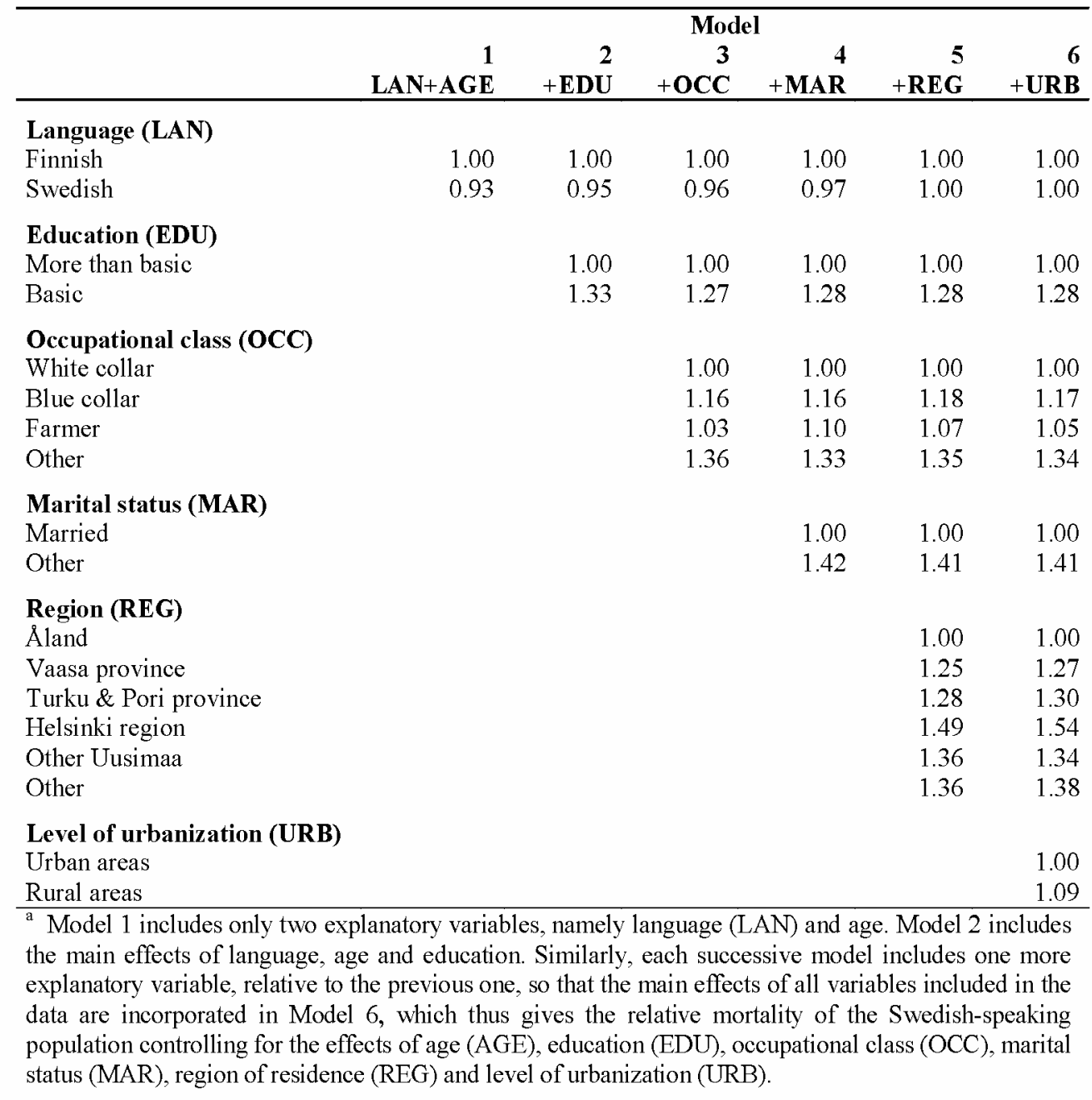

The contrast in age-standardized mortality is much starker in middle-aged men: Swedish-speaking men have a $27 \%$ advantage over the others (relative mortality $=0.73$; Table $3 \mathrm{~b}$ ). Approximately one-third of this variation is related to different socioeconomic and geographic distributions of the language groups. Nevertheless, the relative mortality of the Swedish-speaking men remains low, $83 \%$ of the level among the other men, even after controlling for all variables included in the data. In the subsequent analyses the main emphasis will therefore be put on language-group differences among men. 
Table 3b. Mortality of Swedish-speaking Finns relative to other Finns $(=1.00)$ according to different models ${ }^{\mathrm{a}}$ in men aged 35-64 in 1971-85.

\begin{tabular}{|c|c|c|c|c|c|c|}
\hline & $\begin{array}{r}1 \\
\text { LAN+AGE } \\
\end{array}$ & $\begin{array}{r}2 \\
+ \text { EDU } \\
\end{array}$ & $\begin{array}{r}\text { Mod } \\
\mathbf{3} \\
+\mathbf{O C C} \\
\end{array}$ & $\begin{array}{r}4 \\
+ \text { MAR } \\
\end{array}$ & $\begin{array}{r}5 \\
+ \text { REG } \\
\end{array}$ & $\begin{array}{r}6 \\
+ \text { URB } \\
\end{array}$ \\
\hline \multicolumn{7}{|l|}{ Language (LAN) } \\
\hline Finnish & 1.00 & 1.00 & 1.00 & 1.00 & 1.00 & 1.00 \\
\hline Swedish & 0.73 & 0.76 & 0.77 & 0.78 & 0.83 & 0.83 \\
\hline \multicolumn{7}{|l|}{ Education (EDU) } \\
\hline More than basic & & 1.00 & 1.00 & 1.00 & 1.00 & 1.00 \\
\hline Basic & & 1.47 & 1.33 & 1.30 & 1.30 & 1.30 \\
\hline \multicolumn{7}{|c|}{ Occupational class (OCC) } \\
\hline White collar & & & 1.00 & 1.00 & 1.00 & 1.00 \\
\hline Blue collar & & & 1.28 & 1.20 & 1.21 & 1.20 \\
\hline Farmer & & & 1.02 & 0.98 & 1.00 & 0.97 \\
\hline Other & & & 1.20 & 1.13 & 1.15 & 1.14 \\
\hline \multicolumn{7}{|l|}{ Marital status (MAR) } \\
\hline Married & & & & 1.00 & 1.00 & 1.00 \\
\hline Other & & & & 1.77 & 1.76 & 1.76 \\
\hline \multicolumn{7}{|l|}{ Region (REG) } \\
\hline Aland & & & & & 1.00 & 1.00 \\
\hline Vaasa province & & & & & 1.06 & 1.07 \\
\hline Turku \& Pori province & & & & & 1.06 & 1.08 \\
\hline Helsinki region & & & & & 1.28 & 1.31 \\
\hline Other Uusimaa & & & & & 1.14 & 1.15 \\
\hline Other & & & & & 1.24 & 1.25 \\
\hline \multicolumn{7}{|c|}{ Level of urbanization (URB) } \\
\hline Urban areas & & & & & & 1.00 \\
\hline Rural areas & & & & & & 1.05 \\
\hline
\end{tabular}

\section{Is the mortality difference equally wide in all population groups?}

Table 4 reveals that the relative differences in age-standardized mortality are not equally wide in each subgroup of the population. Part of the diversity obviously results from random variation due to the small number of deaths in many subgroups. Among men mortality of the Swedish speakers is, however, lower than that of the Finnish-speaking majority in each subgroup. Even though controlling for the differences in the sociodemographic structure of the language groups appeared to abolish the mortality differential among women, a significant difference is found in some subgroups. 
Table 4. Mortality of Swedish-speaking persons as percentage of mortality of Finnish-speaking persons in subgroups of the population aged 35-64 in 1971-1985. ( $95 \%$ confidence intervals in parentheses.)

\begin{tabular}{|c|c|c|c|c|c|c|c|c|}
\hline \multirow{3}{*}{$\begin{array}{l}\text { Subgroup } \\
\text { All }\end{array}$} & \multicolumn{4}{|c|}{ Age adjusted } & \multicolumn{4}{|c|}{ All variables ad justed ${ }^{a}$} \\
\hline & \multicolumn{2}{|c|}{ Women } & \multicolumn{2}{|c|}{ Men } & \multicolumn{2}{|c|}{ Women } & \multicolumn{2}{|c|}{ Men } \\
\hline & 93 & $(90-97)$ & 73 & $(71-75)$ & 100 & $(96-104)$ & 83 & $(81-85)$ \\
\hline $\begin{array}{l}\text { Age } \\
35-39 \\
40-44 \\
45-49 \\
50-54 \\
55-59 \\
60-64\end{array}$ & $\begin{array}{r}72 \\
85 \\
108 \\
89 \\
97 \\
93 \\
(\mathrm{p}<.01)\end{array}$ & $\begin{array}{r}(59-88) \\
(73-100) \\
(96-121) \\
(81-98) \\
(91-104) \\
(88-98)\end{array}$ & $\begin{array}{r}65 \\
62 \\
65 \\
73 \\
75 \\
77 \\
(\mathrm{p}<.001)\end{array}$ & $\begin{array}{l}(58-73) \\
(56-69) \\
(60-71) \\
(69-77) \\
(72-79) \\
(74-80)\end{array}$ & $\begin{array}{r}77 \\
92 \\
116 \\
96 \\
105 \\
99 \\
(\mathrm{p}<.01)\end{array}$ & $\begin{array}{r}(63-94) \\
(78-107) \\
(104-131) \\
(88-106) \\
(97-112) \\
(93-104)\end{array}$ & $\begin{array}{r}73 \\
71 \\
74 \\
83 \\
86 \\
87 \\
(\mathrm{p}<.001)\end{array}$ & $\begin{array}{l}(65-83) \\
(64-79) \\
(68-81) \\
(78-89) \\
(81-90) \\
(83-90)\end{array}$ \\
\hline $\begin{array}{l}\text { Education } \\
\text { More than basic } \\
\text { Basic }\end{array}$ & $\begin{array}{r}98 \\
94 \\
(\mathrm{NS})\end{array}$ & $\begin{array}{r}(91-106) \\
(90-98)\end{array}$ & $\begin{array}{r}79 \\
75 \\
\text { (NS) }\end{array}$ & $\begin{array}{l}(75-83) \\
(73-77)\end{array}$ & $\begin{array}{r}102 \\
100 \\
\text { (NS) }\end{array}$ & $\begin{array}{l}(94-110) \\
(96-104)\end{array}$ & $\begin{array}{r}85 \\
82 \\
(\mathrm{NS})\end{array}$ & $\begin{array}{l}(80-89) \\
(80-85)\end{array}$ \\
\hline $\begin{array}{l}\text { Occupational class } \\
\text { White-collar } \\
\text { Blue-collar } \\
\text { Farmer } \\
\text { Other }\end{array}$ & $\begin{array}{r}103 \\
92 \\
84 \\
103 \\
(p<.001)\end{array}$ & $\begin{array}{r}(97-109) \\
(87-98) \\
(77-92) \\
(92-114)\end{array}$ & $\begin{array}{r}85 \\
75 \\
72 \\
73 \\
(p<.001)\end{array}$ & $\begin{array}{l}(81-89) \\
(72-77) \\
(68-76) \\
(67-79)\end{array}$ & $\begin{array}{r}105 \\
97 \\
91 \\
107 \\
(\mathrm{p}<0.05)\end{array}$ & $\begin{array}{l}(99-111) \\
(91-103) \\
(84-100) \\
(96-120)\end{array}$ & $\begin{array}{r}89 \\
81 \\
81 \\
79 \\
(\mathrm{p}<.01)\end{array}$ & $\begin{array}{l}(85-93) \\
(78-84) \\
(76-86) \\
(73-86)\end{array}$ \\
\hline $\begin{array}{l}\text { Marital status } \\
\text { Married } \\
\text { Other }\end{array}$ & $\begin{array}{r}96 \\
93 \\
(\mathrm{NS})\end{array}$ & $\begin{array}{r}(92-100) \\
(88-98)\end{array}$ & $\begin{array}{r}76 \\
71 \\
(p<0.05)\end{array}$ & $\begin{array}{l}(74-79) \\
(68-75)\end{array}$ & $\begin{array}{r}102 \\
98 \\
\text { (NS) }\end{array}$ & $\begin{array}{l}(97-107) \\
(92-103)\end{array}$ & $\begin{array}{r}84 \\
79 \\
(p<0.05)\end{array}$ & $\begin{array}{l}(82-87) \\
(75-83)\end{array}$ \\
\hline $\begin{array}{l}\text { Region } \\
\text { Aland } \\
\text { Vaasa province } \\
\text { Turku\&Pori prov. } \\
\text { Helsinki region } \\
\text { Other Uusimaa } \\
\text { Other regions }\end{array}$ & $\begin{array}{r}73 \\
87 \\
100 \\
98 \\
102 \\
97 \\
(\mathrm{p}<.05)\end{array}$ & $\begin{array}{r}(41-131) \\
(80-93) \\
(90-112) \\
(92-105 \\
(94-110) \\
(78-121)\end{array}$ & $\begin{array}{r}57 \\
74 \\
87 \\
78 \\
79 \\
73 \\
(\mathrm{p}<05)\end{array}$ & $\begin{array}{l}(39-84) \\
(71-78) \\
(80-94) \\
(74-82) \\
(75-84) \\
(62-85)\end{array}$ & $\begin{array}{r}74 \\
90 \\
106 \\
104 \\
104 \\
113 \\
(\mathrm{p}<.05)\end{array}$ & $\begin{array}{r}(42-132) \\
(84-97) \\
(95-119) \\
(97-111) \\
(96-112) \\
(90-142)\end{array}$ & $\begin{array}{r}71 \\
78 \\
93 \\
86 \\
81 \\
91 \\
(\mathrm{p}<.01)\end{array}$ & $\begin{array}{r}(48-104) \\
(74-82) \\
(86-100) \\
(82-91) \\
(76-85) \\
(78-106)\end{array}$ \\
\hline $\begin{array}{l}\text { Level of } \\
\text { urbanization } \\
\text { Urban areas } \\
\text { Rural areas }\end{array}$ & $\begin{array}{r}96 \\
89 \\
(p<.05)\end{array}$ & $\begin{array}{r}(92-100) \\
(84-95)\end{array}$ & $\begin{array}{r}77 \\
68 \\
(p<.001) \\
\end{array}$ & $\begin{array}{l}(74-79) \\
(66-71)\end{array}$ & $\begin{array}{r}102 \\
96 \\
\text { (NS) }\end{array}$ & $\begin{array}{r}(98-107) \\
(90-103)\end{array}$ & $\begin{array}{r}85 \\
79 \\
(p<.01)\end{array}$ & $\begin{array}{l}(82-88) \\
(76-83)\end{array}$ \\
\hline
\end{tabular}

${ }^{\mathrm{a}}$ Age and all the other variables (region, level of urbanization, education, occupational class and marital status), except the variable under study, adjusted for.

In men the contrast is much wider than in women, as was already observed above. Furthermore, the relative advantage of the Swedish-speaking persons is particularly manifest in the youngest age groups and among persons residing in rural areas. In addition, the contrast in age-standardized mortality is slightly more pronounced among farmers than in other occupational classes, particularly among women. This finding results, however, partly from the altogether different geographic distribution of the Swedish-speaking and Finnish-speaking agricultural population, which can be seen when the effect of region is adjusted for. Among white-collar men, the contrast is weaker than in the other classes, whether other variables are controlled for or not, and among white-collar women there is a statistically non-significant excess mortality in the Swedish-speaking group. 
Controlling for other variables also somewhat changes the findings for the regional populations. In general, the relative advantage of the Swedish-speaking population declines or, in some instances, even reverses to a slight disadvantage, when their higher socioeconomic position is taken into account. Among both women and men, adjusting for the other sociodemographic variables produces a particularly small change in the results concerning the province of Vaasa as well as for Uusimaa, excluding the Helsinki Region. In these areas the socioeconomic distribution of the Swedish-speaking persons differs only slightly from that in the rest of the population of the respective region. Therefore, when all other variables are controlled for, the relative mortality of the Swedish-speaking men, compared to the other men, is particularly low in Vaasa and "other Uusimaa", in addition to Aland, for which the confidence intervals are very large, however, due to the very small number of deaths in the Finnish-speaking group. Among women the adjustment for other variables leads to the result that it is only in Vaasa that the Swedish speakers have significantly lower mortality than the Finnish-speaking group.

\section{Is the mortality difference similar in all causes of death?}

The advantage of the Swedish speakers is obvious in men's age-adjusted mortality from each cause of death, except neoplasms other than lung cancer. Controlling for all sociodemographic variables diminishes the mortality contrasts but they remain marked and statistically significant (Table 5). The mortality excess of the Finnish-speaking men is largest in cardiovascular and respiratory diseases as well as in non-natural causes of death. Also lung cancer and "other" diseases are more common in the Finnishspeaking group, but the difference is relatively small.

Table 5. Mortality of Swedish-speaking persons as percentage of mortality of Finnish-speaking persons by cause of death in the population aged 35-64 in 19711985. (95\% confidence intervals in parentheses.)

\begin{tabular}{lrrrrrrrr}
\hline Cause of death & \multicolumn{4}{c}{ Women } & \multicolumn{4}{c}{ Men } \\
& \multicolumn{1}{c}{ Age adjusted $^{\text {All adjusted }}$} & \multicolumn{2}{c}{ Age adjusted $^{\mathbf{a}}$} & \multicolumn{2}{c}{ All adjusted $^{\mathbf{a}}$} \\
\hline Ischemic heart disease & 75 & $(69-82)$ & 85 & $(78-94)$ & 69 & $(66-72)$ & 82 & $(78-85)$ \\
Other cardiovascular dis. & 72 & $(66-79)$ & 86 & $(78-94)$ & 64 & $(60-69)$ & 71 & $(66-77)$ \\
Lung cancer & 136 & $(112-166)$ & 127 & $(102-157)$ & 77 & $(71-84)$ & 89 & $(81-97)$ \\
Other neoplasms & 116 & $(109-122)$ & 114 & $(108-122)$ & 106 & $(100-113)$ & 105 & $(98-112)$ \\
Respiratory diseases & 108 & $(89-130)$ & 112 & $(91-139)$ & 65 & $(57-74)$ & 73 & $(63-84)$ \\
Other diseases & 94 & $(86-104)$ & 103 & $(93-115)$ & 80 & $(74-87)$ & 88 & $(81-96)$ \\
Suicide & 94 & $(78-113)$ & 104 & $(85-128)$ & 63 & $(56-71)$ & 70 & $(61-80)$ \\
Other violence \& accidents & 77 & $(66-90)$ & 81 & $(68-97)$ & 62 & $(57-67)$ & 74 & $(68-82)$ \\
All causes & $\mathbf{9 3}$ & $\mathbf{( 9 0 - 9 7 )}$ & $\mathbf{1 0 0}$ & $\mathbf{( 9 6 - 1 0 4 )}$ & $\mathbf{7 3}$ & $\mathbf{( 7 1 - 7 5 )}$ & $\mathbf{8 3}$ & $\mathbf{( 8 1 - 8 5 )}$ \\
\hline
\end{tabular}

${ }^{\mathrm{a}}$ Age, region, level of urbanization, education, occupational class and marital status adjusted for 
Among women the situation is more complex. The language groups do not differ from each other in mortality from all causes combined when the sociodemographic structure of the groups is taken into account. Behind this similarity we find opposite patterns. Finnish-speaking women have statistically significant excess mortality from cardiovascular diseases and violent and accidental causes, excluding suicide. In ischemic heart disease the mortality contrast between the language groups is almost equally great among women and men. On the other hand, mortality from neoplasms is significantly higher among Swedish-speaking than among Finnish-speaking women and smaller differences, in the same direction, are seen also in other diseases and suicides.

Circulatory diseases are responsible for nearly two-thirds of the excess mortality of Finnish-speaking men compared with Swedish-speaking men (Table 6). Together with non-natural deaths, they cause $90 \%$ of the mortality difference in men. For women these two groups of causes of death are the only ones where the Swedish-speaking population has a mortality advantage.

Table 6. Excess mortality (deaths / 100000 / year) of the Finnish-speaking population aged 35-64, compared with the Swedish-speaking population by cause of death in 1971-1985. Age and all other variables ${ }^{\mathrm{a}}$ controlled for.

\begin{tabular}{lcc} 
Cause of death & Women & Men \\
\hline Ischemic heart disease & 11 & 66 \\
Other cardiovascular diseases & 11 & 35 \\
Lung cancer & -2 & 8 \\
Other neoplasms & -19 & -6 \\
Respiratory diseases & -1 & 9 \\
Other diseases & -2 & 9 \\
Suicide & -1 & 16 \\
Other violence \& accidents & 4 & 27 \\
All causes & 0 & 162 \\
\hline a Region, level of urbanization, education, occupational class and marital status
\end{tabular}

The cause-specific analyses were carried out also in regional and other subgroups of the population. Due to small numbers of deaths, causes of death were combined into circulatory diseases, neoplasms, other diseases, and accidental and violent causes. In circulatory diseases, wide and statistically significant variation was found in the extent of language-group differences. The findings replicated those in mortality from all causes, presented in Table 4 . When all other factors were controlled for, a particularly large advantage of the Swedish-speaking population in mortality from circulatory diseases was observed in Alland and the province of Vaasa, in rural areas and in the agricultural population, and among the younger middle-aged men. 
In other causes of death, the language-group contrast varied significantly between subgroups of the population only in some instances. In women's accidental and violent deaths the Swedish-speaker's advantage was particularly large in Aland, in the province of Vaasa, in Uusimaa excluding the Helsinki Region and among blue-collar employees. In mortality from neoplasms among men, blue-collar workers had a widerthan-average contrast between language groups. In male mortality from other diseases the difference was especially evident in the provinces of Vaasa and Uusimaa, in rural areas and among farmers.

\section{Conclusions}

The mortality advantage of the Swedish-speaking Finns is partly due to their favorable geographic location and socioeconomic position. Owing to the history of the settlement of Finland, the Swedish-speaking population resides in the western coastal areas where mortality is low in both language groups, and the proportion of higher socioeconomic groups is larger than average in the Swedish-speaking population. For women these factors appear to totally explain the difference in mortality from all causes but among men, two-thirds of the original difference, a $20 \%$ excess mortality of the Finnish-speaking majority, persists after adjusting for the structural differences.

It turns out, however, that even among women a mortality difference emerges in certain subgroups and in some causes of death. This implies that the structural explanation suggested by the first step of the analysis is partly biased and it is due to differences taking place in opposite directions. Moreover, it has been shown elsewhere (Martelin 1994) that among elderly women the excess mortality of the Finnish-speaking majority persists even after controlling for the sociodemographic structure.

Clues for possible causes of the difference, other than the structural explanation, have been searched for by means of separately analyzing various subgroups as well as causes of death. To summarize, the advantage of the Swedish-speaking group is particularly large in the younger age groups, especially among men, and in Åland, followed by Vaasa, and, with respect to men, 'other Uusimaa'. In addition, the mortality contrast appears to be slightly wider among manual workers than among non-manual workers, and in rural than in urban areas, even when the other sociodemographic variables are controlled for.

After adjusting for structural differences between the language groups, excess mortality among the Finnish speakers, relative to the Swedish-speaking persons, is seen for both genders only in cardiovascular diseases as well as in accidental and violent deaths. In ischemic heart disease the relative mortality difference between the language groups is equally great among both sexes, whereas in other cardiovascular diseases and non-natural causes the advantage is more evident for Swedish-speaking 
men than women. In neoplasms other than lung cancer, a slight mortality excess is seen among Swedish-speaking women and men. All the other causes of death show opposite language-group differences for women and for men.

The following assessment of reasons, other than population structure, for the causespecific findings is divided in three parts. We shall first discuss the most important question, i.e. the reasons for the low mortality from circulatory diseases among Swedishspeaking women and men. Next, possible causes for the difference in accidental and violent deaths will be considered. Finally, we shall attempt to evaluate why the mortality differences between language groups are opposite among women and men for most of the remaining causes of death.

Swedish-speaking women and men seem to possess some feature(s) which protect(s) them from dying of circulatory diseases and non-natural causes. It seems likely that the causes of these mortality differences between the language groups are rather similar for women and men. What could these features be? The results presented above fit best with the genetic and cultural hypotheses: the mortality contrast is seen in all population groups but it is starkest in those subgroups which have assumably maintained their original cultural and genetic characteristics, i.e. farmers, persons living in Åland and Vaasa province and those residing in rural areas. Social networks (Hyyppä and Mäki 2001a, 2001b) and dietary practices are among the cultural factors which might come into question as mechanisms mediating the effect.

In addition to cardiovascular diseases, accidental and violent deaths are also less common among Swedish-speaking men and women as compared to the Finnish-speaking population, the difference being greater among men. One of the causes for this phenomenon may lie in differences in patterns of the use of alcohol. In the early 1970s, mortality of Finnish-speaking men from selected alcohol-related diseases ${ }^{2}$ was about $20 \%$ higher compared with mortality among Swedish-speaking men, while deaths from alcohol poisoning were as much as four times more common among Finnishspeaking than Swedish-speaking men (Valkonen 1982). Valkonen's results imply that, among men, there were large differences between the language groups in drinking habits. This finding parallels the survey results reported by Simpura (1990).

Of the causes of death included in this study, excessive alcohol use is mainly related with non-natural deaths and the heterogeneous group 'other diseases' which together account for about $30 \%$ of the mortality difference between Swedish- and Finnishspeaking men. Among male deaths from non-natural causes, alcohol plays a role in less than half of the cases (Koskinen and Martelin 1994, 184). Among deaths from

${ }^{2}$ Cirrhosis of the liver, diseases of the pancreas, alcoholism and alcoholic psychosis 
'other diseases', the corresponding proportion can hardly be higher. We may thus approximate that the impact of excessive alcohol consumption on the mortality difference between the language groups probably lies somewhere between $10-30 \%$ among men.

The language group differences in alcohol-related causes of death were small among women. This corresponds with the survey findings suggesting that drinking habits among Swedish-speaking women are almost similar to those in the general female population (Simpura 1990). As a result, mortality differences among women can not be explained by differences in drinking habits - unless one is willing to propose that the way the Finnish-speaking men use alcohol is dangerous to Finnish-speaking women.

In addition to patterns of drinking, some other causal factors behind the mortality advantage of the Swedish speakers appear to be specific to men only. Swedish-speaking men are less vulnerable than Finnish-speaking men regarding all remaining causes of death except neoplasms other than those of the lung. Genetic and general environmental factors could hardly provide an adequate explanation because they would probably exert their effect similarly on both genders. Behavioral patterns, on the other hand, show considerable variation between women and men. Differences in lung cancer mortality suggest that Finnish-speaking men smoke more than Swedish-speaking men. Five percent of the excess deaths among Finnish-speaking men were due to lung cancer, as was shown in Table 6. As lung cancer has been estimated to cause about one-third of smoking-related deaths (Martelin and Valkonen 1981; Peto and Lopez 1992), we can conclude that, among men, about $15 \%$ of the excess mortality of the Finnish speakers is due to differences in smoking habits between the language groups.

The other causes of death where the effect of differences in smoking habits can be seen are mainly respiratory and cardiovascular diseases. Among men, deaths from circulatory diseases account for more than $60 \%$ of the mortality difference between the language groups. The advantage of the Swedish-speaking men in mortality from cardiovascular diseases is, therefore, mainly due to other etiological factors. In women, lung cancer and respiratory diseases were more common in the Swedish-speaking population. This finding indicates that smoking has been more common among Swedish-speaking than Finnish-speaking women. While differences in smoking habits between the language groups appear to run in opposite directions in women and men, the greater difference among men, compared with women, in cardiovascular mortality between the language groups may largely ensue from smoking patterns.

In summary, there is no simple all-embracing answer to the question of why mortality is low in the Swedish-speaking population of Finland. The contrast is partly due to their favorable geographic location and socioeconomic position, but differences in genetic factors as well as behavioral patterns or other cultural factors are likely to be 
important causes as well. While a comprehensive data set consisting of census variables and information from death certificates provides an excellent basis for testing the hypothesis of the effect of structural differences, the possibilities for drawing conclusions about the role of genetic or cultural factors are limited.

\section{References}

Aitkin, M. and D. Clayton. 1980. The fitting of exponential, Weibull and extreme value distributions to complex censored survival data using GLIM. Applied Statistics, 29, pp. 156163.

Allardt, E. 1979. Implications of the Ethnic Revival in Modern, Industrialized Society: a Comparative Study of the Linguistic Minorities in Western Europe. Commentationes Scientiatum Socialium 12. Helsinki: Societas Scientiarum Fennica.

Allardt, E. and C. Starck. 1981. Vähemmistö, kieli ja yhteiskunta. [Minority, language and society, in Finnish]. Porvoo: WSOY.

Balarajan, R., L. Bulusu, A.M. Adelstein, and V. Shukla. 1984. Patterns of mortality among migrants to England and Wales. British Medical Journal, 289, pp. 185-187.

Bollini, P. and H. Siem. 1995. No real progress towards equity: health of migrants and ethnic minorities on the eve of the year 2000. Social Science \& Medicine 41(:6):819-828.

Central Statistical Office of Finland. 1952. Statistical Yearbook of Finland 1951. Helsinki: Central Statistical Office of Finland.

Central Statistical Office of Finland. 1987. Structure of Population and Vital Statistics, 1985: Whole country and provinces. Official statistics of Finland VIA:151:1. Helsinki: Central Statistical Office of Finland.

Finnäs, F. 1986. The Demographic Development of the Swedish Population in Finland 19501980. (In Swedish with an English summary). Skrifter utgivna av Svenska litteratursällskapet i Finland, nr 533. Helsingfors: Svenska litteratursällskapet i Finland.

Finnäs, F. 1995. Finlandssvenskarna 1993: en statistisk översikt. [The Swedish-speaking population in Finland 1993: a statistical overview; in Swedish]. Finlandssvensk rapport nr 29. Helsingfors: Svenska Finlands Folkting.

Fougstedt, G 1951. Finlands Svenska Befolkning Aren 1936-1945. Bidrag till kännedom af Finlands natur och folk, häfte 95, n:o 2. Helsingfors.

Hyyppä, M. 1994. Mitä rannikon miesten terveydestä voisi oppia? [What could we learn from the health of men residing on the coast?; in Finnish]. Suomen Lääkärilehti, 49, pp. 494-495.

Hyyppä, M.T. and J. Mäki. 2001a. Why do Swedish-speaking Finns have longer active life? An area for social capital research. Health Promotion International 16(:1):55-64.

Hyyppä, M.T. and J. Mäki. 2001b. Individual-level relationships between social capital and self-rated health in a bilingual community. Preventive Medicine 43(:2):148-155.

Kornitzer, M., G. de Backer, M. Dramaix, and C. Thilly. 1979. Regional differences in risk factor distributions, food habits and coronary heart disease mortality and morbidity in Belgium. International Journal of Epidemiology, 8, pp. 23-31.

Koskinen, S. 1994. Origins of Regional Differences in Mortality from Ischaemic Heart Disease in Finland. STAKES, Studies 41. Jyväskylä: Gummerus.

Koskinen, S. and T. Martelin. 1994. Kuolleisuus. [Mortality; in Finnish]. In: Suomen Väestö, edited by S. Koskinen, T. Martelin, I.-L. Notkola, V. Notkola, and K. Pitkänen pp. 150-225. Helsinki: Gaudeamus.

Martelin, T. 1984. The Development of Smoking Habits According to Survey Data in Finland. (In Finnish with an English summary). Publications of the National Board of Health, series 
original reports 1/1984. Helsinki: National Board of Health.

Martelin, T. 1994. Differential Mortality at Older Ages: sociodemographic mortality differences among the Finnish elderly. Publications of the Finnish Demographic Society 16. Helsinki: The Finnish Demographic Society.

Martelin, T. and T. Valkonen. 1981. Tupakointimuutokset ja keski-ikäisten miesten kuolleisuus Suomessa vuosina 1950-75 sekä laskelmia vuoteen 2000. [Changes in smoking habits and mortality of middle-aged men in Finland in 1950-75 and calculations up to the year 2000; in Finnish]. University of Helsinki, Department of Sociology, Working Papers 19.

Payne, C. (ed.). 1985. The GLIM system. Release 3.77, manual. Oxford: The Numerical Algorithms Group, Royal Statistical Society.

Peto, R., A. Lopez, J. Boreham, M. Thun, and C. Heath. 1992. Mortality from tobacco in developed countries: indirect estimation from national vital statistics. Lancet, 339, 1268-1278.

Salminen, S. and A. Johansson. 2000. Occupational accidents of Finnish- and Swedish-speaking workers in Finland: a mental model view. International Journal of Occupational Safety and Ergonomics 6(:2):293-306.

Sandlund, T. 1985. Suomenruotsalaiset. (The Swedish-speaking population in Finland; in Finnish). In: Suomalaiset - yhteiskunnan rakenne teollistumisen aikana, edited by T. Valkonen, R. Alapuro, M. Alestalo, R. Jallinoja, and T. Sandlund, pp. 271-290. Porvoo: WSOY.

Sauli, H. 1979. Ammatti ja kuolleisuus 1971-75. (Occupation and mortality 1971-75, in Finnish). Studies 54, Helsinki: Central Statistical Office of Finland.

Simpura, J. (ed.) 1987. Finnish drinking habits: results from interview surveys held in 1968 , 1976 amd 1984. Studies 35. Helsinki: The Finnish Foundation for Alcohol Studies.

Simpura, J. 1990. Drinking patterns among the Swedish speaking population of Finland. (In Swedish with an English summary). Finska Läkaresällskapets Handlingar, 150, 168-170.

Statistics Finland 200 la. Statistical Yearbook of Finland 2001. Helsinki: Statistics Finland.

Statistics Finland 200 lb. Vital Statistics 2000. Helsinki: Statistics Finland.

Stephens, M. 1976. Linguistic Minorities in Western Europe. Llandysul, Dyfed, Wales: Gomer Press.

Suominen, S.B., R.S. Välimaa, J.A. Tynjälä, and L.K. Kannas. 2000. Minority status and perceived health: a comparative study of Finnish- and Swedish-speaking schoolchildren in Finland. Scandinavian Journal of Public Health 28(:3):179-187.

Uitenbroek, D.G. and A.P. Verhoeff. 2002. Life expectancy and mortality differences between migrant groups living in Amsterdam, The Netherlands. Social Science \& Medicine 54(:9):1379-1388.

Valkonen, T. 1982. Sociodemographic mortality differentials among middle-aged men and problems in accounting for them. University of Helsinki, Department of Sociology, Working Papers 25.

Valkonen, T. 1991. Assumptions about mortality trends in industrialized countries: a survey. In: Future demographic trends in Europe and North America, edited by W. Lutz, pp. 3-25. London: Academic Press.

Valkonen, T., T. Martelin, and A. Rimpelä. 1990. Socioeconomic mortality differences in Finland 1971-85. Studies 176. Helsinki: Central Statistical Office of Finland.

Valkonen, T., T. Martelin, A. Rimpelä, V. Notkola, and S. Savela. 1993. Socio-economic mortality differences in Finland 1981-90. Population 1993:1. Helsinki: Statistics Finland.

Virtaranta-Knowles, K., P. Sistonen, and H.R. Nevanlinna. 1991. A population genetic study in Finland: comparison of the Finnish- and Swedish-speaking populations. Human Heredity, 41, pp. 248-264.

Wild, S. and P. Mckeigue. 1997. Cross sectional analysis of mortality by country of birth in England and Wales, 1970-92. British Medical Journal 314(:7082):705-710. 